\title{
СКЛИФОСОВСКИЙ Николай Васильевич (к 180-летию со дня рождения)
}

\begin{abstract}
Н.В. Склифосовский - крупный ученый, выдающийся хирург, замечательный педагог, блестящий организатор, автор более 110 научных работ, посвященных самым разнообразным разделам хирургии; участник австропрусской (1866-1868), франко-прусской (1870-1871), балканской (1876) и русскотурецкой (1877-1878) войн, награжден орденами Св. Владимира II степени с мечами, Св. Владимира III степени с мечами (Российская империя); Железный Крест, Красный Орёл (Пруссия); Св. Даниила III степени (Черногория), заслуженный профессор.

В 1871 году Н. В. Склифосовский перешел на кафедру хирургической патологии в Императорскую медико-хирургическую академию в Петербург, но в 1871 г. Николай Васильевич - консультант на театре военных действий в Черногории на Балканах, в 1878-1879 гг. - ведущий хирург русской армии в русско-турецкой войне, где был награжден орденом Святого Владимира 3-й степени с мечами и дослужился до генерала. В 1874 году Н.В. Склифосовским одним из первых была произведена операция иссечения зоба, что положило начало развитию хирургии щитовидной железы.
\end{abstract}

Н.В. Склифосовский родился 25 марта 1836 г. на хуторе Карантин близ города Дубоссары Тираспольского уезда Херсонской губернии в небогатой украинской дворянской семье. В семье было 12 детей, девятым был Николай, которого для воспитания отправили в Одесский дом для сирот, находившийся в ведении Приказа общественного призрения.

Как воспитанник сиротского дома Н.В.Склифосовский был принят во 2-ю Одесскую мужскую гимназию, которую в 1854 году окончил с серебряной медалью и дипломом «с отличием», предоставлявшим льготы при поступлении в университет. В ноябре 1854 г. Николай Васильевич был принят в Московский университет на бесплатное обучение и на казенное содержание Одесского Приказа общественного призрения. На 5 курсе Н.В.Склифосовский был допущен к докторским экзаменам, на основании которых был признан достойным степени лекаря с отличием, с правом защиты диссертации на степень доктора медицины.

После окончания университета Н.В.Склифосовский устраивается в Одесскую городскую больницу, где с 1860 по 1866 г. работает ординатором хирургического отделения, с 1868 по 1870 гг. - заведующим хирургическим отделением Одесской городской больницы.

В 1863 году он успешно защитил диссертацию в Харьковском университете на тему: «О кровяной околоматочной опухоли» и получил ученую степень доктора медицины. В 1864 г. он вторым в России после А.Я. Крассовского выполнил овариэктомию. В 1866 году Н.В. Склифосовский поступил на военную службу в прусскую армию в должности полкового врача, что позволило ему попасть на обучение в Европу, где он обучался у Р. Вирхова, Лангенбека, Нелатона, Мальгеня, Кламара, Д. Листера, Симпсона, Бильрота, Вернейля и Гиртля. В 1867 г. Николай Васильевич впервые в России успешно удалил пораженные опухолью матку и придатки.

По рекомендации Н.И. Пирогова Н.В. Склифосовскому предлагают место профессора в Киевском университете. Но 8 марта 1870 г., прочитав вступительную лекцию в университете, Николай Васильевич уезжает на франко-прусскую войну в должности полкового врача прусской армии.
3 марта 1878 г. Н.В. Склифосовский был утвержден в должности руководителя академической (факультетской) хирургической клиники. В 1879 г. Николай Васильевич впервые на человеке выполнил одномоментную гастростомию по поводу рака пищевода.

В 1880 г. Н.В. Склифосовский единогласно был избран руководителем кафедры факультетской хирургической клиники Московского университета. В 1882 г. он избран деканом медицинского факультета.

В 1882 г. Николай Васильевич в числе первых выполнил резекцию желудка по поводу рака, в 1885 году - провел наложение гастроэнтероанастомоза; первый в России выполнил чресплевральную эхинококкэктомию при вскрытии эхинококкового пузыря в бронхиальное дерево.

В 1885 г. в клинике Н.В. Склифосовского впервые в России с успехом был применён внутрикостный металлоостеосинтез, причём в качестве металлического стержня были использованы золочёные гвозди; в 1877 г. дал объяснение перитониального шока, усматривая основную его причину в запредельных воздействиях на брюшину различных раздражителей в процессе операции, реализуемых посредством нервно-рефлекторных механизмов. Николай Васильевич был в 1887 г. организатором и председателем 2-го съезда русских врачей. В своем докладе он изложил взгляды на образование и пути их решения.

В 1893 году впервые в России Николай Васильевич организовал и возглавил институт усовершенствования врачей в Петербурге. В августе 1897 г. в Москве состоялся XII Международный съезд врачей, на котором присутствовали более 7000 врачей со всего мира, президентом съезда был Н.В. Склифосовский.

В 1897 году в его клинике впервые в России состоялась демонстрация применения рентгеновских лучей в диагностических целях. В 1900 году Н.В. Склифосовский председательствовал на І съезде русских хирургов.

В 1901 г. у Николая Васильевича случился мозговой инсульт. Последние 4 года жизни он тяжело болел. В 1902 г. по состоянию здоровья он выходит в отставку и уезжает в свою усадьбу под Полтавой. 30 ноября 1904 г. Н.В. Склифосовский скончался.

Подготовлена А.А. Андреев, А.П. Остроушко 